\title{
GAGASAN KEDAULATAN LINGKUNGAN DALAM KONSTITUSI DAN IMPLEMENTASINYA DALAM PELESTARIAN LINGKUNGAN HIDUP
}

\author{
Sodikin \\ Fakultas Hukum, Universitas Muhammadiyah Jakarta \\ Jl. K.H. Ahmad Dahlan, Cireundeu, Kota Tangerang Selatan, Banten \\ sodikinsadali68@gmail.com
}

\begin{abstract}
The Amendment to the 1945 Constitution has contained the notion of new sovereignty, namely environmental sovereignty. The idea of environmental sovereignty has given a new thought in terms of sovereignty, namely the highest power in a country. The environment has become a supreme power in the life of Indonesian constitutional. The concept of environmental sovereignty is implicitly regulated in Article 25A. Article $28 \mathrm{H}$ paragraph (1) and Article 33 paragraph (3) and (4) of the 1945 Constitution. These articles give a green nuance to the 1945 Constitution, so that the implementation of the articles in the 1945 Constitution provides new thinking for the legislators so that the concept of environmental sovereignty can be realized in every Law made. There are several laws that have given a green nuance such as laws that regulate human rights issues, sustainable economic development and the territory of the country with the concept of archipelago insight.
\end{abstract}

Keywords: Environmental Sovereignty; Constitution; Human Rights; Sustainable Development; Territory of the Country

\begin{abstract}
Abstrak
Amandemen UUD 1945 telah melahirkan ajaran kedaulatan baru yaitu kedaulatan lingkungan. Gagasan kedaulatan lingkungan telah memberikan pemikiran baru dalam hal kedaulatan, yaitu kekuasaan tertinggi dalam suatu negara. Lingkungan hidup telah menjadi suatu kekuasaan tertinggi dalam kehidupan ketatanegaraan Indonesia. Konsep kedaulatan lingkungan secara jelas diatur dalam Pasal 25A, Pasal 28H ayat (1) dan Pasal 33 ayat (3) dan (4). Pasal-pasal tersebut memberikan nuansa hijau terhadap UUD 1945, sehingga implementasi dari pasal-pasal dalam UUD 1945 tersebut memberikan pemikiran baru bagi pembuat Undang-Undang agar konsep kedaulatan lingkungan hidup dapat terwujud dalam setiap Undang-undang yang dibuat. Ada beberapa undang-undang telah memberikan nuansa hijau seperti undang-undang yang mengatur masalah hak asasi manusia, pembangunan perekonomian berkelanjutan dan wilayah negara dengan konsep wawasan nusantara.
\end{abstract}

Kata Kunci: Kedaulatan Lingkungan; Konstitusi; Hak Asasi Manusia; Pembangunan Berkelanjutan; Wilayah Negara

\section{A. Pendahuluan}

Gagasan kedaulatan lingkungan dalam UUD 1945 tidak dapat dilepaskan dari proses amandemen UUD 1945 itu sendiri. Amandemen UUD 1945 telah mengubah system ketatanegaraan Indonesia, yang mencerminkan pola kehidupan masyarakat yang mengikuti pola perkembangan peradaban dan globalisasi dunia yang sudah melanda ke seluruh dunia termasuk Indonesia. Oleh karena itu, amandemen UUD 1945 tersebut telah memberikan pemahaman baru tentang konsep kedaulatan lingkungan. Menurut Jimly Asshidiqie, kedaulatan adalah konsep 
mengenai kekuasaan tertinggi dalam suatu negara (Asshiddiqie, 1994). Kedaulatan merupakan padanan istilah sovereignty (bahasa Inggris), souverainete (bahasa Perancis), souvereiniteit (bahasa Belanda), sovranus (bahasa Italia), istilah-istilah asing ini berasal dari kata Latin "Superanus" yang mempunyai arti tertinggi (Anwar C., 2008). Konsep kedaulatan yang berarti kekuasaan yang tertinggi dalam suatu negara yang berarti kekuasaan pemerintahan dalam suatu negara untuk kepentingan warga negaranya.

Selanjutnya berkaitan dengan kedaulatan, maka hal yang penting yaitu mengenai siapakah pemegang dan pelaksana kedaulatan, bagaimana melaksanakan kedaulatan itu dan siapakah yang menjadi objek kedaulatan. Menurut Jack H. Nagel, bahwa dalam setiap analisis mengenai konsep kekuasaan ada dua hal yang terkait yaitu lingkup kekuasaan (scope of power) dan jangkauan kekuasaan (domain of power). Lingkup kekuasaan menunjuk pada kegiatan, tingkah laku serta sikap dan keputusan-keputusan yang menjadi objek dari kekuasaan, sedangkan jangkauan kekuasaan berkaitan dengan siapa yang menjadi subjek dan pemegang kekuasaan atau kedaulatan (Budiarjo, 1986).

Menyangkut siapa yang berdaulat dalam suatu negara, UUD 1945 mengenal beberapa ajaran kedaulatan. Sri Soemantri mengemukakan 4 (empat) teori kedaulatan, yaitu Kedaulatan Tuhan, Kedaulatan Negara, Kedaulatan Hukum dan Kedaulatan Rakyat (Soemantri, 1984). Pertama, gagasan kedaulatan Tuhan dalam UUD 1945 terdapat kata Tuhan yang disebut sebanyak 4 (empat) kali yaitu kata "Allah" disebut dua kali dan kata "Tuhan" dan "Ketuhanan". Kata "Allah" terdapat dalam Alinea Ketiga Pembukaan UUD 1945, yaitu, "Atas berkat rahmat Allah Yang Maha Kuasa dan dengan didorong oleh keinginan yang luhur,..." begitu juga dalamPasal 9 ayat (1) UUD 1945 tentang Sumpah Jabatan Presiden/Wakil Presiden, yaitu, "Demi Allah, saya bersumpah akan memenuhi kewajiban Presiden Republik Indonesia (Wakil Presiden Republik Indonesia) dengan sebaik-baiknya....". Sedangkan kata "Tuhan" terdapat dalam rumusan Alinea Keempat Pembukaan yang dikenal sebagai rumusan sila pertama Pancasila, dan kata "Ketuhanan" terdapat dalam Pasal 29 ayat (1) UUD 1945 yang menyatakan "Negara berdasar atas Ketuhanan Yang Maha Esa".

Kedua, kedaulatan negara dalam UUD 1945 dapat ditemukan dalam Pasal 30 ayat (3) UUD 1945 yang menyatakan, "Tentara Nasional Indonesia terdiri atas Angkatan Darat, Angkatan Laut, dan Angkatan Udara sebagai alat negara bertugas mempertahankan, melindungi dan memelihara keutuhan dan kedaulatan negara". Ketentuan konstitusional ini membebankan kepada Tentara Nasional Indonesia (TNI) sebagai alat negara untuk menjaga keutuhan dan kedaulatan negara yang berarti bertugas mempertahankan, melindungi dan memelihara keutuhan dan kedaulatan negara. Awal mula adanya ajaran kedaulatan negara muncul di Jerman, yaitu untuk mempertahankan kedudukan raja yang pada waktu itu mendapat dukungan dari tiga lapisan masyarakat yang besar pengaruhnya, yaitu golongan bangsawan (Jurkertum), golongan angkatan perang (Militair), dan golongan alat-alat pemerintah (birokrasi) (Kusnardi \& Saragih, 1994). Pelopor utama teori kedaulatan negara adalah George Jellinek mengemukakan bahwa negara adalah organisasi yang dilengkapi sesuatu kekuatan asli, kekuatan yang bukan didapat dari sesuatu kekuatan yang lebih tinggi derajatnya, hukum diciptakan oleh negara sendiri dan setiap gerak-gerik manusia dalam negara itu harus menurut kehendak negara, sedangkan negara sendiri tidak perlu takluk di bawah hukum, karena negara sendiri yang membuat hukum (Lubis, 1972).

Ketiga, kedaulatan hukum ini tercermin dalam pengertian Negara Hukum yang tercantum dalam Pasal 1 ayat (3) UUD 1945 yang menyatakan "Negara Indonesia adalah negara hukum". Ajaran kedaulatan hukum yang ditentukan dalam Pasal 1 ayat (3) tersebut juga berhubungan dengan Pasal 1 ayat (2) UUD 1945 yang menyatakan bahwa, "kedaulatan berada di tangan rakyat dan dilaksanakan menurut Undang-Undang Dasar". Maksud Undang-Undang Dasar dalam 
Pasal 1 ayat (2) tersebut menunjukkan bahwa Undang-Undang Dasar sebagai Hukum Dasar Tertulis.

Menurut Jimly Asshiddiqie, paham negara hukum yang diutamakan adalah hukum sebagai suatu kesatuan sistem bernegara, sistem yang paling tinggi kekuasaannya bukanlah orang tetapi sistem aturan yang dinamakan hukum. Hukumlah yang sesungguhnya berdaulat, bukan orang, sehingga pemegang kekuasaan yang tertinggi dalam suatu negara adalah hukum, yang pengaturannya pada tingkat puncak atau tertinggi tercermin dalam konstitusi negara yaitu the rule of the constitution. Di negara kita, hukum yang mempunyai kedudukan tertinggi adalah UUD Negara Republik Indonesia Tahun 1945 (Asshiddiqie, 2009, p. 108). Oleh karena hukum mempunyai kedudukan yang tertinggi, maka hukum haruslah ditegakkan, sebab apabila hukum tidak ditegakkan maka tidak akan ada gunanya hukum tersebut. Tegaknya hukum akan menjadi pengatur dan pengontrol semua aktivitas atau kegiatan manusia.

Keempat, gagasan kedaulatan rakyat terkandung dalam UUD 1945 terdapat dalam Alinea Keempat Pembukaan UUD 1945 dan Pasal 1 ayat (2) UUD 1945. Alinea Keempat Pembukaan UUD 1945 menyatakan, “...maka disusunlah kemerdekaan kebangsaan Indonesia itu dalam suatu Undang-Undang Dasar Negara Indonesia yang terbentuk dalam suatu susunan Negara Republik Indonesia yang berkedaulatan rakyat dengan berdasar kepada... dan kerakyatan yang dipimpin oleh hikmat kebijaksanaan dalam permusyawaratan/perwakilan". Pasal 1 ayat (2) UUD 1945 menyatakan, "Kedaulatan berada di tangan rakyat dan dilaksanakan menurut Undang-Undang Dasar". Menurut Jimly Asshiddiqie, prinsip kedaulatan rakyat tercermin dalam keseluruhan mekanisme dan prosedur-prosedur yang diatur dalam UUD 1945, seperti prosedur rekrutmen politik, mekanisme penyusunan kebijakan atau fungsi legislasi, prosedur pengawasan legislatif terhadap pelaksanaan kekuasaan dan sebagainya (Asshiddiqie, 2009, p. 105). Menurut ajaran kedaulatan rakyat berarti rakyat berdaulat, berkuasa untuk menentukan bagaimana rakyat diperintah dalam rangka mencapai tujuan Negara (Sodikin, 2014). Tujuan negara adalah sebagaimana ditentukan dalam Pembukaan UUD 1945, yaitu rakyat menjadi sejahtera.

Selain keempat gagasan kedaulatan tersebut, UUD 1945 telah mengadopsi ide mengenai pentingnya lingkungan hidup dalam system kekuasaan di negara Indonesia, sehingga muncullah gagasan kedaulatan lingkungan. Kedaulatan lingkungan yang berarti kekuasaan atas suatu negara ada pada lingkungan hidup, atau alam sebagai jagat raya mendapat posisi dan kedudukan yang lebih tinggi dalam arti dalam setiap pengelolaan negara bahwa lingkungan hidup mendapat kedudukan yang tinggi. Hal inilah yang menjadi state of the art tulisan ini dari tulisantulisan sebelumnya yang pernah ada.

Gagasan kedaulatan lingkungan tersebut ditentukan dalam Pasal $28 \mathrm{H}$ ayat (1) UUD 1945 tentang hak asasi manusia yaitu hak atas lingkungan hidup yang baik dan sehat yaitu dinyatakan bahwa, "Setiap orang berhak hidup sejahtera lahir dan bathin, bertempat tinggal, dan mendapatkan lingkungan hidup yang baik dan sehat serta berhak memperoleh pelayanan kesehatan". Begitu juga dalam Pasal 33 ayat (4) UUD 1945 mengenai pentingnya prinsipprinsip pembangunan berkelanjutan (sustainable development) dan prinsip pembangunan yang berwawasan lingkungan yaitu dinyatakan bahwa, "Perekonomian nasional diselenggarakan berdasar atas demokrasi ekonomi dengan prinsip kebersamaan, efisiensi berkeadilan, berkelanjutan, berwawasan lingkungan, kemandirian, serta dengan menjaga keseimbangan kemajuan dan kesatuan ekonomi nasional".

Selain dua pasal tersebut, masih berkaitan dengan lingkungan hidup dalam UUD 1945 yaitu Pasal 33 ayat (3) UUD 1945 yang menyatakan, "Bumi dan air dan kekayaan alam yang terkandung di dalamnya dikuasai oleh negara dan dipergunakan untuk sebesarbesarnya kemakmuran rakyat", dan juga Pasal 25A UUD 1945 yang menyatakan bahwa, "Negara Kesatuan Republik Indonesia adalah 
sebuah negara kepulauan yang berciri Nusantara dengan wilayah yang batas-batas dan hak-haknya ditetapkan dengan undangundang".

Dengan demikian, penulis mencoba menganalisisnya dengan permasalahan yang muncul yaitu mengenai cakupan pengertian konseptual gagasan kedaulatan lingkungan yang dirumuskan dalam UUD 1945 dan bagaimana alam pikiran itu dijabarkan dalam rumusan kebijakan perundang-undangan dalam rangka pelaksanaan UUD 1945.

\section{B. Pembahasan}

\section{Gagasan Konseptual Kedaulatan Lingkungan Dalam Amandemen UUD 1945}

Amandemen UUD 1945 telah melahirkan pemikiran baru di bidang lingkungan hidup, pemikiran baru tentang lingkungan hidup tersebut telah mengubah paradigma baru dalam penyelenggaraan negara di Indonesia. Kehidupan kenegaraan Indonesia yang mengharuskan kembali kepada alam semesta ini dan mengembalikan kepada kehidupan yang secara alamiah yaitu sesuai, selaras dan seimbang dengan lingkungan hidup. Amandemen UUD 1945 menempatkan lingkungan hidup mempunyai makna kekuasaan yang sebenarnya dalam segala aspek kehidupan. Oleh karena itu, menurut Sri Soemantri, umumnya UUD 1945 atau konstitusi berisi tiga hal pokok. Pertama, adanya jaminan terhadap hak-hak asasi manusia dan warga negara, kedua, ditetapkannya susunan ketatanegaraan suatu negara yang berisi fundamental, dan yang ketiga, adanya pembagian dan pembatasan tugas ketatanegaraan yang bersifat fundamental (Soemantri, 2006). Sifat fundamental ialah yang sangat hakiki, dan sifat hakiki itulah yang sebenarnya kehidupan manusia itu kembali kepada alam. Demikian juga Pancasila sebagai filosofi bangsa telah mengajarkan tentang kehidupan alamiah Indonesia yaitu kembali kepada alam semesta.

Selanjutnya juga dikatakan Jimly Asshiddiqie, bahwa gagasan kedaulatan lingkungan yang kemudian disebut dengan gagasan ekokrasi dalam konteks kekuasaan yang dikonstruksikan dalam mekanisme hubungan antara Tuhan, Alam dan Manusia. Selama ini, di zaman modern relasi kekuasaan hanya dipandang sebagai persoalan manusia. Pandangan ini dikenal dengan istilah anthroposentrisme yang menempatkan kehidupan terpusat pada manusia. Dibandingkan pada masa sebelumnya, terutama di zaman pra-modern, pandangan yang tersirat anthroposentris ini tentu dapat dianggap lebih maju dan lebih baik (Asshiddiqie, 2009, p. 117). Tuhan yang menciptakan alam beserta isinya termasuk manusia, sehingga kehidupan manusia harus seimbang dengan alam semesta atau alam lingkungannya, dan alam harus dipandang memiliki hak-hak dalam konsteks kekuasaan. Tidak hanya manusia yang diberi status sebagai subyek hukum, tetapi lingkungan juga mempunyai hak yang sama diberi status sebagai subyek hukum. Dikatakan oleh Jimly Asshiddiqie, bahwa alam dan manusia dipandang sama-sama merupakan subyek hakhak yang bersifat asasi. Oleh sebab itu, seperti halnya manusia, alam juga memegang kekuasaan di bidang atau dalam hal-hal tertentu juga bersifat tertinggi, sehingga hal itu dapat disebut sebagai kedaulatan lingkungan (Asshiddiqie, 2009, p. 128).

Manusia yang merupakan komponen lingkungan hidup yang paling sempurna di antara komponen lingkungan lainnya, maka menurut Kusnadi Hardjasoemantri, dengan kelebihannya atas populasi-populasi yang lain, manusia mengemban tugas dan kewajiban untuk mengatur adanya keselarasan dan keseimbangan antara keseluruhan ekosistem baik ekosistem alamiah maupun ekosistem buatan (Hardjasoemantri, 2002). Demikian yang dimaksudkan dan yang diinginkan dalam filosofi Pancasila sebagai dasar negara yang kemudian diimplementasi dalam hukum dasar tertulis yaitu UUD 1945. Hal ini dikarenakan masyarakat Indonesia dalam kenyataannya lebih akrab dengan lingkungan alamnya dari pada dengan lingkungan teknologi. Keadaan alam masih lebih menentukan untuk sebagian besar masyarakat Indonesia daripada upaya teknologi. Perkembangan teknologi yang mengelola sumber daya alam harus 
memberikan manfaat yang sebesar-besarnya bagi kesejahteraan rakyat dengan tetap memperhatikan keseimbangan dan kelestariannya sehingga akan tetap bermanfaat bagi generasi mendatang (Soerjani \& Et.al., 1997).

Dengan demikian, UUD 1945 menganut paham kedaulatan lingkungan dengan konsep kedaulatan lingkungan yang dikaitkan dengan istilah ekokrasi atau kekuasaan ekologi, dimana manusia sebagai salah satu komponen lingkungan hidup yang mempunyai peranan yang besar dalam lingkungan, itulah kemudian UUD 1945 menganut paham kedaulatan lingkungan.

Ketentuan mengenai lingkungan hidup dirumuskan pada saat amandemen UUD 1945, yaitu Pasal 28H ayat (1) dan Pasal 33 ayat (4) UUD 1945. Gagasan lingkungan hidup masuk dalam materi muatan hak asasi manusia, yaitu dimulainya perubahan materi hak asasi manusia. Sebenarnya gagasan untuk memuat hak asasi manusia dalam Undang-Undang Dasar sudah diperdebatkan pada saat founding father merumuskan UUD sebagai dasar negara, yang salah satunya tentang perlu tidaknya pengaturan tentang HAM dicantumkan dalam UUD. Hal ini terlihat perdebatan antara Soekarno dan Soepomo dengan M. Hatta dan M. Yamin pada saat Rapat BPUPKI yang diselenggarakan pada tanggal 15 Juli 1945 (Yamin, 1959). Pada akhirnya pada 16 Juli 1945 perdebatan dalam BPUPKI menghasilkan kompromi sehingga diterima beberapa ketentuan dalam UUD (Joeniarto, 1984). Salah satu hasil kompromi adalah mencatumkan beberapa pasal tentang HAM.

UUD 1945 yang disahkan oleh PPKI pada tanggal 18 Agustus 1945 yang memang bersifat singkat dan supel, sehingga masalah HAM yang ada di dalamnya tidak banyak, termasuk hak atas lingkungan yang baik dan sehat tidak ditemukan dalam UUD 1945. Berbeda halnya dengan Konstitusi RIS 1949 dan UUDS 1950 yang memuat lebih banyak tentang HAM, termasuk di dalamnya memuat juga masalah hak atas lingkungan hidup.

Dalam perjalanan sejarah kehidupan kenegaraan berikutnya, yaitu era reformasi dengan menguatnya pemenuhan hak asasi manusia dengan melalui amandemen UUD 1945, masalah hak asasi manusia mendapatkan porsi yang pertama selain demokratisasi. Pembahasan mengenai masalah HAM sudah disinggung dalam Rapat PAH PAH III BP MPR RI ke-2. Rapat yang diketuai M. Amien Rais mengusung agenda Pemandangan Umum Fraksi tentang materi Sidang Umum MPR sesuai Bidang Tugas PAH BP MPR. Dalam Pemandangan Umum Fraksi tentang Materi Sidang Umum, Vincent Radja dari F-KKI menyinggung masalah HAM agar dipertegas secara detail dalam UUD 1945 (Mahkamah Konstitusi Republik Indonesia, 2010a). Perubahan UUD 1945 mengenai HAM dalam pembahasan PAH III BPR MPR Tahun 1999.

Fraksi-fraksi yang lain juga sama menyampaikan pandangan umum tentang perubahan pasal hak asasi manusia, termasuk perlunya ketentuan yang lebih rinci mengenai hak asasi manusia. Begitu juga dalam rapat ketiga PAH I BP MPR yang dilaksanakan pada 6 Desember 1999 yang diketuai oleh Jakob Tobing, bahwa tiap-tiap fraksi melalui juru bicaranya membacakan kata pengantar dan pandangan umum yang terkait dengan masalah hak asasi manusia. Pada umumnya fraksi-fraksi memberikan pernyataan tentang perubahan pasal hak asasi manusia, pemahaman hak asasi manusia dan perlunya hak asasi manusia itu diatur lebih rinci dalam Undang-Undang Dasar 1945.

Pada masa sidang berikutnya, yaitu rapat PAH I BP MPR yang ke-17 mengundang kelompok profesional yaitu Ikatan Sarjana Ekonomi Indonesia (ISEI) dan Kamar Dagang Indonesia (Kadin), dan juga diundang Yayasan Lembaga Bantuan Hukum Indonesia (YLBI) dan Pusat Bantuan Hukum dan HAM Indonesia (PBHI). Salah seorang perwakilan ISEI, Ichsan Tanjung menjelaskan pengaruh demokrasi dan hak asasi terhadap ekonomi yang memberi contoh isu lingkungan yang berkembang di Indonesia.

"Kita mendengar bagaimana hasil-hasil hutan kita juga akan terkena hal semacam itu. Jadi, akan ada ecolabelling di negaranegara Eropa semacam itu. Dan jangan kaget kalau produksi kita akan 
dipertanyakan berdasakan input-input yang disampaikan oleh LSM di sini ke luar negeri bahwa itu diproduksi secara melanggar HAM entah upahnya, entah fasilitas ini itu, kesehatan, wanita hamil masih dipekerjakan. Saya kira contohcontohnya akan semakin banyak.

Jadi, yang kami mau garis bawahi di sini bahwa Bapak Ibu sekalian ekonomi pun tidak bisa lepas dari HAM dan demokrasi. Itu juga satu alasan mengapa kita memandang ada yang tidak benar, kalau itu dipercayakan pada penyelenggara negara yang sangat berkuasa dan bisa memainkan banyak hal. Jadi, diserahkan kepada swasta tetapi dengan asumsi dasar hukum harus berlaku, dan dalam rangka memberlakukan hukum ini kita jangan keder dengan LSM, banyak fungsinya mereka itu” (Sekretariat Jenderal MPR RI, 2008, p. 205).

Dalam rapat PAH I BP MPR-RI ke-42, tanggal 12 Juni 2000 yang diketuai Jakob Tobing, diagendakan pembahasan rumusan Bab X mengenai Warga Negara. Pembahasan mengenai Warga Negara banyak terkait dengan masalah hak asasi manusia. Ada beberapa usulan yang disampaikan oleh fraksifraksi di MPR berkaitan dengan pasal-pasal hak asasi manusia. Pembahasan dalam PAH I dirumuskan menjadi sebuah naskah rancangan perubahan UUD 1945. Hasil rumusan rancangan dari PAH I diputuskan menjadi usul BP MPR yang diajukan ke Sidang Tahunan MPR RI Tahun 2000 yang kemudian membentuk alat kelangkapan Majelis. Di antara alat kelengkapan Majelis berupa Komisi Majelis, terdapat Komisi A yang khusus bertugas membahas rancangan putusan dari BP MPR tersebut tentang perubahan UUD 1945.

Dalam rapat Komisi A membahas mengenai usulan-usulan yang berasal dari naskah rancangan perubahan UUD mengenai HAM dari berbagai pihak dalam PAH I BP MPR untuk dimasukkan atau tidak dalam rumusan pasal-pasal hak asasi manusia. Usulan-usulan yang dibahas dalam rapat I sampai V Komisi A kemudian disimpulkan pada Rapat VI Komisi. Pemimpin Rapat Komisi A yaitu Hamdan Zoelva menyampaikan kesimpulan sebagai berikut:

“... Baik Bapak-bapak dan Ibu-ibu sekalian, apa perlu saya bacakan.

Bab XA

Hak Asasi Manusia

Pasal 28 (A): ...

Pasal 28 H ayat (1) "Setiap orang berhak hidup sejahtera lahir dan bathin, bertempat tinggal, dan mendapatkan lingkungan hidup yang baik dan sehat serta berhak memperoleh pelayanan kesehatan" (Sekretariat Jenderal MPR RI, 2008, pp. 514-517).

Selanjutnya hasil pembahasan Komisi A dilaporkan ke Rapat Paripurna Sidang Tahunan MPR yang berlangsung dari $7-18$ Agustus 2000. Akhirnya rancangan perubahan tersebut disetujui untuk diputuskan pada Rapat Paripurna Sidang Tahunan MPR-RI ke-9 tanggal 18 Agustus 2000. Pada akhirnya rumusan hak atas lingkungan masuk dalam Bab yang mengatur hak asasi manusia, yaitu Bab XA Undang-Undang Dasar Negara Republik Indonesia Tahun 1945, yang dimulai dari Pasal 28A sampai Pasal 28J. Adapun pasal yang khusus mengenai hak atas lingkungan hidup yang baik dan sehat adalah Pasal $28 \mathrm{H}$ ayat (1).

Hak atas lingkungan hidup yang baik dan sehat adalah hak paling asasi dan hakiki yang tidak bisa dikurangi dan manusia dapat menikmati lingkungan hidup yang baik dan sehat. Hal ini karena lingkungan hidup merupakan satu kesatuan ekologi yang juga merupakan suatu daur kehidupan (recyling) atau suatu ekosistem dimana manusia ada di dalamnya. Ekosistem yang merupakan suatu hubungan timbal balik antara berbagai komponen lingkungan untuk mendukung keberlanjutan lingkungan hidup atau ekologi itu sendiri. Dalam hubungan yang timbal balik ini, diperlukan adanya keseimbangan dan keselarasan ekologi, yaitu suatu keadaan bahwa makhluk hidup ada dalam hubungan yang harmonis dengan lingkungannya, sehingga terjadi keseimbangan dan keselarasan interaksi antar makhluk hidup dan 
lingkungannya. Dari semua makhluk hidup, manusialah yang paling mampu untuk beradaptasi dengan lingkungannya. Apabila manusia tidak mampu dalam menjaga dan melindungi lingkungan, maka terjadilah pencemaran, perusakan dan kerusakan lingkungan. Pencemaran dan perusakan itulah yang menjadi masalah bagi hidup dan kehidupan umat manusia. Oleh karena itu, komponen lingkungan hidup yang namanya manusia yang dapat melakukan tindakan pencegahan pencemaran dan perusakan lingkungan hidup.

Gagasan mengenai kedaulatan lingkungan juga ditemukan dalam perubahan Pasal 33 yang sebelumnya tiga ayat kemudian ditambahkan ayat lagi mengenai konsepsi lingkungan hidup yaitu pada saat membahas perekonomian nasional dan kesejahteraan sosial. Pada rapat Komisi A ke-4, 8 Agustus 2002 telah dihasilkan Perubahan Keempat UUD 1945 hasil pembahasan di Komisi A. Hasil tersebut selanjutnya akan disampaikan pada Rapat Paripurna Majelis esok harinya 9 Agustus 2002. Namun terhadap pasal-pasal yang belum disepakati secara bulat, Komisi A, 8 Agustus 2002 membentuk Tim Lobi dan Tim Perumus. Adapun Rancangan Perubahan Keempat UUD 1945 yang dihasilkan Komisi A tentang Perekonomian Nasional dan Kesejahteraan adalah berupa penambahan dua ayat baru pada Pasal 33. Pasal 33 ayat (4), yaitu "Perekonomian

Nasional diselenggarakan atas demokrasi ekonomi dengan prinsip kebersamaan, efisiensi, berkeadilan, berkelanjutan, berwawasan lingkungan, kemandirian, serta dengan menjaga keseimbangan kemajuan dan kesatuan ekonomi nasinal" (Mahkamah Konstitusi Republik Indonesia, 2010b). Mengenai Pasal 33 tentang Perekonomian Nasional, seluruh fraksi MPR dapat menyepakati rumusan Komisi A dan seluruh anggota MPR yang hadir menyetujui pengesahan rumusan pasal tersebutdalam forum Rapat Paripurna ST MPR 2002 ke-6 yang diselenggarakan pada 10 Agustus 2002. Dengan demikian, rumusan tersebut ditetapkan menjadi bagian dari Perubahan Keempat UUD 1945.
Berkaitan dengan Pasal 33 ayat (4), yaitu ayat (3) nya yang menyatakan, "Bumi dan air dan kekayaan alam yang terkandung di dalamnya dikuasai oleh negara dan dipergunakan untuk sebesar-besarnya kemakmuran rakyat". Bumi, air dan kekayaan alam yang terkandung di dalamnya juga meliputi ruang angkasa merupakan satu kesatuan lingkungan hidup yang kemudian disebut sebagai ekosistem. Menurut Boedi Harsono, yaitu ruang di atas bumi dan air yang mengandung tenaga dan unsur-unsur yang dapat digunakan untuk usaha-usaha memelihara dan memperkembangkan kesuburan bumi, air serta kekayaan alam yang terkandung di dalamnya dan hal-hal lainnya yang bersangkutan dengan itu (Harsono, 1995). Oleh karena itu, dalam pengelolaan bumi, air dan kekayaan alam memperhatikan ekosistem yang menurut konsep UUD 1945 bahwa perekonomian nasional berdasar atas demokrasi ekonomi dimaksud haruslah mengandung prinsip (i) berkelanjutan, dan (ii) berwawasan lingkungan (Asshiddiqie, 2009, p. 94).

Selanjutnya masih berkaitan dengan kedaulatan lingkungan adalah Pasal 25A UUD 1945 yang menyatakan, "Negara Kesatuan Republik Indonesia adalah sebuah negara kepulauan yang berciri Nusantara dengan wilayah yang batas-batas dan hak-haknya ditetapkan dengan undang-undang". Pasal mengenai wilayah negara ini merupakan ketentuan baru dalam UUD 1945. Ketentuan ini menjadi usulan beberapa fraksi untuk dimasukkan ke dalam UUD 1945. Hal ini terlihat dalam substansi perdebatan dalam rapat-rapat yang khusus membahas wilayah negara. Perdebatan dan rumusan akhir pasal tentang wilayah negara baru bisa disepakati dalam Rapat Paripurna Komisi A, hari Senin, 14 Agustus 2000. Setelah seluruh fraksi menerima rancangan yang telah disampaikan oleh Komisi A melalui tanggapan akhir fraksifraksi pada Rapat Paripurna ke-8, dan pada tanggal 18 Agustus 2000 Ketua MPR RI M. Amin Rais mengesahkan BAB IXA tentang Wilayah Negara yang terdapat dalam Pasal $25 \mathrm{~A}$. 
Menurut ketentuan Pasal 25A UUD 1945 tersebut menunjukkan bahwa, pengertian ruang lingkup lingkungan hidup Indonesia adalah seluruh wilayah Negara Kesatuan Republik Indonesia dari Sabang sampai Merauke yang merupakan suatu kedaulatan negara. Ruang lingkup lingkungan hidup Indonesia meliputi ruang, tempat Negara Kesatuan Republik Indonesia yang berWawasan Nusantara dalam melaksanakan kedaulatan, hak berdaulat, dan yurisdiksinya (Sodikin, 2018). Hal ini berarti dalam pengelolaan lingkungan hidup Indonesia menempati ruang tempat Negara Kesatuan Republik Indonesia yang mempunyai kedaulatan dengan jelas batas wilayah wewenang pengelolaannya.

Secara hukum, lingkungan hidup Indonesia meliputi ruang tempat Negara Kesatuan Republik Indonesia melaksanakan kedaulatan dan hak-hak berdaulat serta yurisdiksinya. Dalam hal ini lingkungan hidup Indonesia tidak lain adalah wilayah yang menempati posisi silang antara dua samudera dan dua benua dengan iklim tropis dan cuaca serta musim yang memberikan kondisi alam dan kedudukan dengan peranan strategis yang tinggi nilainya sebagai tempat rakyat dan bangsa Indonesia menyelenggarakan kehidupan berbangsa, bernegara dan bermasyarakat. Dengan demikian, wawasan dalam menyelenggarakan pengelolaan lingkungan hidup adalah wawasan nusantara. Hal ini karena kondisi obyektif geografi nusantara yang terdiri atas ribuan pulau yang tersebar dan terbentang di khatulistiwa serta terletak pada posisi silang yang sangat strategis, memiliki karakteristik yang berbeda dengan negara lain.

\section{Pelaksanaan Kedaulatan Lingkungan Dalam Perundang-undangan}

Lazim dipahami bahwa UUD 1945 setelah amandemen menganut ajaran kedaulatan lingkungan yang secara tegas dirumuskan dalam pasal-pasal sebagaimana dijelaskan di atas. Dengan mendalami berbagai perundangundangan sebagai implementasi ketentuan tentang kedaulatan lingkungan yang memberikan pemahaman bagi pelaksana kedaulatan dalam mengambil kebijakan untuk membuat undang-undang sesuai dengan amanat UUD 1945.

Pertama, hak atas lingkungan hidup yang baik dan sehat sebagaimana dimaksud dalam Pasal 28H ayat (1) UUD 1945 memberikan makna yang mendalam bagi semua pihak dalam rangka untuk memenuhi hak setiap warga masyarakat terhadap lingkungan hidup baik dan sehat. Hak atas lingkungan hidup yang baik dan sehat menunjukkan bahwa setiap orang untuk meningkatkan kualitas hidup dan kehidupan manusia diperlukan lingkungan hidup yang baik dan sehat. Di sini perlunya pemenuhan hak atas lingkungan hidup yang baik dan sehat yang diberikan oleh negara. Pasal 28H ayat (1) UUD 1945 kemudian diimplementasi dalam UndangUndang Nomor 39 Tahun 1999 tentang Hak Asasi Manusia, yaitu dalam Pasal 9 ayat (3) yaitu: "Setiap orang berhak atas lingkungan hidup yang baik dan sehat" (meskipun Undang-undang Nomor 39 Tahun 1999 lahir sebelum amandemen UUD 1945). Demikian juga dijelaskan dalam Undang-Undang Nomor 32 Tahun 2009 tentang Perlindungan dan Pengelolaan Lingkungan Hidup, terutama dalam Pasal 65 ayat (1) menyatakan: "setiap orang berhak atas lingkungan hidup yang baik dan sehat sebagai bagian dari hak asasi manusia".

Adanya hak atas lingkungan yang baik dan sehat sebagaimana ditentukan dalam dalam Pasal 28H ayat (1) UUD 1945, sehingga perlunya perlindungan dan pemenuhan hak asasi manusia di bidang lingkungan hidup yang juga berarti melindungi hak asasi manusia sekaligus melindungi lingkungan hidup. Hak atas lingkungan hidup yang baik dan sehat termasuk mendapatkan lingkungan hidup yang bersih (right to a clean environment) yang dapat dipilah menjadi hak untuk hidup, hak mendapat kehidupan yang layak, hak untuk mendapatkan kesehatan serta hak untuk mendapatkan kebebasan atas harta benda, yang tidak boleh dilupakan adalah perlindungan HAM yang sangat berkaitan dengan lingkungan hidup yaitu perlindungan terhadap indigenous people/local community.

Hak untuk hidup (right to life) dapat terganggu akibat kerusakan atau tercemarnya 
lingkungan hidup yang berakibat terganggunya kesehatan manusia, misalnya terjadi ledakan reaktor nuklir yang mengakibatkan ribuan orang meninggal atau menderita cacat seumur hidup akibat radiasi. Hak atas Lingkungan yang sehat (the right to healthy environment) yang berarti setiap orang berhak untuk mendapatkan kehidupan yang sehat. Hak atas kesehatan (the right to healthy) yang berarti hak setiap orang untuk mendapatkan fisik dan mental sehat. Kesehatan manusia harus tetap terjaga dari polusi, polusi mempunyai dampak negatif terhadap kesehatan manusia. Misalnya infeksi saluran pernapasan atas (ISPA) yang seringkali terjadi di daerah berpolusi karena asap dari kebakaran hutan, atau gatal-gatal kulit yang diderita penduduk yang hidup di sekitar sungai yang tercemar. Hak untuk Bebas dari Segala Intervensi atas Harta Benda (the right to be free interference of One's Home and Property). Maksud hak ini adalah bebas dari gangguan lingkungan, seperti polusi karena kebisingan, banjir dari sebuah bendungan, dan perubahan iklim akibat aktivitas pusat tenaga nuklir yang secara nyata akan mempengaruhi kehidupan seseorang. Hak indigenous people adalah sekelompok bangsa yang berdiam di suatu negara akan tetapi kondisi ekonomi, sosial dan kebudayaannya berbeda dengan masyarakat di wilayah lain serta dalam kehidupannya mereka menggunakan adat istiadat mereka sendiri. Indigenous People seringkali menderita akibat perebutan sumber daya alam yang terdapat di sekitar tempat tinggal mereka, dan yang lebih bahaya, mereka sering dituduh sebagai penyebab degradasi lingkungan hidup, seperti peristiwa kebakaran hutan.

Kedua, masalah pembangunan perekonomian yang berwawasan lingkungan hidup sebagaimana ditentukan dalam Pasal 33 ayat (4) dan juga berkaitan dengan ayat (3) UUD 1945. Adanya pembangunan berkelanjutan ini sebenarnya dimulai dari Konferensi PBB tentang Lingkungan Hidup Manusia (United Nations Conference on the Human Environmental) tahun 1972 di Stockholm Swedia. Hasil-hasil Konferensi Stockholm mendorong perkembangan pengelolaan lingkungan di Indonesia. Prinsip
Eco Development yang dihasilkan dalam Deklarasi Stockholm telah diintegrasikan ke dalam Pasal 3 Undang-Undang Nomor 4 Tahun 1982 tentang Ketentuan-Ketentuan Pokok Pengelolaan Lingkungan Hidup, yaitu pengelolaan lingkungan hidup berasakan pelestarian kemampuan lingkungan yang serasi dan seimbang untuk menunjang pembangunan yang beresinambungan bagi peningkatan kehidupan manusia (Murwaji, 2009). Selanjutnya isu lingkungan internasional terus berkembang yang menghasilkan beberapa konferensi tentang lingkungan hidup yang berkaitan dengan pengelolaan lingkungan untuk kehidupan manusia yaitu pembangunan berkelanjutan menghendaki adanya pola pembangunan berwawasan lingkungan yang menghasilkan Pasal 33 ayat (4) UUD 1945.

Pasal 33 ayat (4) UUD 1945 tersebut telah melahirkan Undang-Undang Nomor 32 Tahun 2009 tentang Perlindungan dan Pengelolaan Lingkungan Hidup. Undang-Undang ini memberikan panduan dalam rangka pembangunan yang dilaksanakan harus selaras, serasi dan seimbang dengan lingkungan. Pasal 2 Undang-undang Nomor 32 Tahun 2009 menjelaskan tentang asas-asas dalam perlindungan dan pengelolaan lingkungan hidup, dan melalui asas-asas tersebut berarti setiap aktivitas pembangunan berasaskan sebagaimana ditentukan dalam Pasal 2 Undang-Undang Nomor 32 Tahun 2009.

Materi yang diatur dalam Undang-Undang Nomor 32 Tahun 2009 sangat luas yang mencakup segi ruang, kekayaan alam yang meliputi sumber daya manusia, sumber daya alam hayati, sumber daya alam non hayati dan sumber alam buatan. Materi yang diatur dalam Undang-Undang Nomor 32 Tahun 2009 tidak mungkin diatur secara lengkap, tentunya akan memerlukan seperangkat peraturan perundangundangan dengan arah dan ciri yang serupa. Dengan demikian,Undang-Undang Nomor 32 Tahun 2009 berfungsi sebagai payung (Undang-Undang Payung atau umbrella act) bagi penyusunan peraturan perundangundangan lainnya tentang perekonomian dan pembangunan yang berkaitan dengan 
perlindungan dan pengelolaan lingkungan hidup serta sebagai penyesuai bagi peraturan perundang-undangan yang sudah ada.

Hal ini sebagai ditentukan dalam Pasal 44 Undang-Undang Nomor 32 Tahun 2009, yang menyatakan bahwa, "Setiap penyusunan peraturan perundang-undangan pada tingkat nasional dan daerah wajib memperhatikan perlindungan fungsi lingkungan hidup dan prinsip perlindungan dan pengelolaan lingkungan hidup sesuai dengan ketentuan yang diatur dalam Undang-Undang ini”. Begitu juga dalam penjelasan umum UndangUndang Nomor 32 Tahun 2009 angka 5 menjelaskan bahwa, “...perlu dikembangkan satu system hukum perlindungan dan pengelolaan lingkungan hidup yang jelas, tegas, dan menyeluruh guna menjamin kepastian hukum sebagai landasan bagi perlindungan dan pengelolaan sumber daya alam serta kegiatan pembangunan lain".

Sebagai upaya dalam menegakkan perundang-undangan untuk melindungi lingkungan hidup dapat ditempuh beberapa upaya penegakan hukum dengan berbagai instrument penegakan hukum yang dikenal dalam Undang-Undang Nomor 32 Tahun 2009 seperti melalui instrument hukum administrasi, hukum perdata dan hukum pidana. Melalui cara tersebut diharapkan selain akan menimbulkan efek jera juga akan meningkatkan kesadaran seluruh pemangku kepentingan tentang betapa pentingnya perlindungan dan pengelolaan lingkungan hidup demi kehidupan generasi masa kini dan masa depan.

Ketiga, masalah pengelolaan lingkungan hidup Indonesia tidak terlepas dari luas wilayah negara sebagaimana ditentukan dalam Pasal 25A UUD 1945, bahwa "Negara Kesatuan Republik Indonesia adalah sebuah negara kepulauan yang berciri Nusantara dengan wilayah yang batas-batas dan hakhaknya ditetapkan dengan undang-undang". Dalam hal ini lingkungan hidup Indonesia tidak lain adalah wilayah yang menempati posisi silang antara dua benua dan dua samudera dengan iklim tropis dan cuaca serta musim yang memberikan kondisi alam dan kedudukan dengan peranan strategis yang tinggi nilainya sebagai tempat rakyat dan bangsa Indonesia menyelenggarakan kehidupan berbangsa, bernegara dan bermasyarakat dengan segala aspeknya.

Ruang lingkup lingkungan hidup Indonesia ialah wilayah yang tersedia dan terbentuk secara alamiah oleh alam nyata. Kondisi obyektif demikian merupakan suatu ruang gerak hidup bangsa Indonesia yang di dalamnya terdapat sumber kekayaan alam dan penduduk yang mempengaruhi pengambilan keputusan politik negara. Dengan demikian, wawasan dalam menyelenggarakan pengelolaan lingkungan hidup Indonesia ialah wawasan nusantara. Munadjat Danusaputro menyatakan, wawasan nusantara adalah cara pandang bangsa dan negara Indonesia tentang diri dan lingkungannya, yang (nyatanya) sarwa-nusantara (bersifat serba nusantara). Wawasan nusantara memandang perwujudan Indonesia sebagai satu kesatuan utuh menyeluruh, baik dari aspek fisik alamiah maupun dari aspek social politik ialah citra lingkungan hidup nusantara (Danusaputro, 1985). Pernyataan itu menunjukkan bahwa lingkungan hidup Indonesia menurut konsep kewilayahan nusantara merupakan pengertian hukum.

Menurut Koesnadi, sebagai pengertian politik, Indonesia dengan penggambarannya dalam semboyan satu bangsa, satu tanah air, satu bahasa dan satu bendera, merupakan sesuatu yang lebih besar artinya daripada kumpulan pulau-pulau yang beribu-ribu jumlahnya itu (Hardjasoemantri, 1999). Dengan demikian, lahirlah konsep negara nusantara melalui Deklarasi Djuanda pada 13 Desember 1957. Deklarasi tersebut untuk keutuhan territorial dan untuk melindungi kekayaan negara yang terkandung di dalamnya, pulau-pulau dan laut-laut yang ada di antaranya harus dianggap sebagai satu kesatuan yang bulat dan utuh. Untuk mengukuhkan asas negara kepulauan ini ditetapkan melalui Undang-undang Nomor 4/PrpTahun 1960 tentang Perairan Indonesia.

Selanjutnya konsep nusantara sebagai manifestasi pemikiran politik Indonesia ditetapkan sebagai wawasan nusantara di dalam Ketetapan MPR No. IV Tahun 1973. 
Dalam pergaulan internasional, melalui konvensi PBB tentang Hukum Laut Internasional yang ketiga tahun 1982, konsep negara kepulauan (nusantara) diakui oleh negara-negara peserta konvensi PBB tersebut. Konvensi tentang PBB tentang Hukum Laut 1982 itu dikenal dengan United Nation Convention on the Law of the Sea (UNCLOS). Indonesia meratifikasi UNCLOS 1982 melalui Undang-Undang Nomor 17 Tahun 1985 pada tanggal 31 Desember 1985. Sebelumnya lahirlah Undang-Undang Nomor 5 Tahun 1983 tentang Zona Ekonomi Eksklusif Indonesia. Undang-Undang Nomor 5 Tahun 1983 ini untuk mendukung perwujudan Wawasan Nusantara dalam rangka meningkatkan kesejahteraan Bangsa Indonesia dengan memanfaatkan segenap sumber daya alam baik hayati maupun non hayati yang terdapat di zona ekonomi eksklusifnya.

Amandemen UUD 1945 melalui Pasal 25A melahirkan Undang-undang Nomor 43 Tahun 2008 tentang Wilayah Negara dan Undang-undang Nomor 32 Tahun 2014 tentang Kelautan. Kedua undang-undang ini lahir karena pengelolaan lingkungan mengharuskan Negara Kesatuan Republik Indonesia sebagai negara kepulauan memiliki sumber daya alam yang melimpah yang merupakan rahmat dan karunia Tuhan Yang Maha Esa bagi seluruh bangsa dan Negara Indonesia yang harus dikelola secara berkelanjutan untuk memajukan kesejahteraan umum. Pengaturan mengenai wilayah negara beserta lautnya bertujuan untuk menegaskan Indonesia sebagai negara kepulauan berciri nusantara dan maritime sehingga memberikan kepastian hukum dan manfaat bagi seluruh masyarakat Indonesia.

\section{Simpulan}

Konsep kedaulatan lingkungan sebagaimana dirumuskan dalam UUD 1945 setelah amandemen UUD 1945 memberikan pemikiran baru dalam kehidupan ketatanegaraan Indonesia. Gagasan kedaulatan lingkungan menguat pada saat amandemen karena kondisi kehidupan bangsa yang harus kembali kepada alam semesta sebagai bagian dari kehidupannya. Perlunya pembangunan yang dilaksanakan dengan segala aspeknya harus selaras, sesuai dan seimbang secara alamiah dengan lingkungannya. Nuansa hijau UUD 1945 yang ditegaskan dalam Pasal 25A, Pasal 28H ayat (1), Pasal 33 ayat (3) dan (4) menunjukkan bahwa UUD 1945 menganut ajaran kedaulatan lingkungan

Gagasan kedaulatan lingkungan dalam UUD 1945 yang kemudian diimplementasikan dalam beberapa perundang-undangan. Rumusan kebijakan perundang-undangan itu dalam rangka pelaksanaan UUD 1945 untuk memberikan nuansa hijau seperti dalam pemenuhan dan pelindungan hak asasi manusia, pembangunan perekonomian melalui pembangunan berkelanjutan dan wawasan nusantara yang merupakan batasan pengelolaan lingkungan hidup di wilayah Negara Kesatuan Republik Indonesia.

\section{DAFTAR PUSTAKA}

Anwar C. (2008). Teori dan Hukum Konstitusi, Paradigma Kedaulatan Pasca Perubahan UUD 1945, Implikasi dan Implementasinya Pada Lembaga Negara. Malang: In-Trans Publishing.

Asshiddiqie, J. (1994). Gagasan Kedaulatan Rakyat Dalam Konstitusi dan Pelaksanaannya di Indonesia. Jakarta: Ichtiar Baru Van Hoeve.

Asshiddiqie, J. (2009). Green Constitution: Nuansa Hijau Undang-Undang Dasar Negara Republik Indonesia Tahun 1945. Jakarta: Rajawali Press.

Budiarjo, M. (1986). Aneka Pemikiran Tentang Kuasa dan Wibawa. Harian Sinar Harapan, p. 14.

Danusaputro, M. (1985). Hukum Lingkungan Buku II: Nasional. Jakarta: Binacipta.

Hardjasoemantri, K. (1999). Hukum Tata Lingkungan. Yogyakarta: Gadjah Mada University Press.

Hardjasoemantri, K. (2002). Hukum Tata Lingkungan. Yogyakarta: Gadjah Mada University Press.

Harsono, B. (1995). Hukum Agraria Indonesia: Sejarah Pembentukan Undang-Undang Pokok Agraria, Isi dan Pelaksanaannya. Jakarta: Djambatan.

Joeniarto, J. (1984). Sejarah Ketatanegaraan 
Republik Indonesia. Jakarta: Bina Aksara. Kusnardi, M., \& Saragih, B. R. (1994). Ilmu Negara. Jakarta: Gaya Media Pratama.

Lubis, S. (1972). Hukum Tata Negara. Bandung: Mandar Maju.

Mahkamah Konstitusi Republik Indonesia. (2010a). Naskah Komprehensif Perubahan Undang-Undang Dasar Negara Republik Indonesia Tahun 1945. Jakarta: Sekretariat dan Kepaniteraan MK RI.

Mahkamah Konstitusi Republik Indonesia. (2010b). Naskah Komprehensif Perubahan Undang-Undang Dasar Negara Republik Indonesia Tahun 1945, Buku VII Keuangan, Perekoomian Nasional dan Kesejahteraan Sosial. Jakarta: Sekretariat Jenderal dan Kepaniteraan Mahkamah Konstitusi.

Murwaji, T. (2009). Hukum Ekonomi Lingkungan Paradigma Baru Pertanggungjawaban Pengelolaan Sumber Daya Alam. Bandung: Yayasan Ibnu Syarikah.
Sekretariat Jenderal MPR RI. (2008). Risalah Perubahan Undang-Undang Dasar Negara Republik Indonesia Tahun 1945 (1999-2002) Tahun Sidang 2000 Buku Dua. Jakarta: Sekretariat Jenderal MPRRI.

Sodikin. (2014). Hukum Pemilu: Pemilu Sebagai Praktek Ketatanegaraan. Bekasi: Gramata Publishing.

Sodikin, S. (2018). Penegakan Hukum Lingkungan Menurut Undang-Undang Nomor 32 Tahun 2009 Tentang Perlindungan dan Pengelolaan Lingkungan Hidup. Bogor: In Media.

Soemantri, S. (1984). No Title. In P. Wahyono (Ed.), Masalah Ketatanegaraan Indonesia Dewasa Ini (p. 67). Jakarta: Ghalia Indonesia.

Soemantri, S. (2006). Prosedur dan Sistem Perubahan Konstitusi. Bandung: Alumni.

Soerjani, M., \& Et.al. (1997). Lingkungan: Sumber daya alam dan Kependudukan Dalam Pembangunan. Jakarta: UI Press.

Yamin, M. (1959). Naskah Persiapan Undang-Undang Dasar 1945, Jilid Pertama. Jakarta: Yayasan Prapanca. 